\title{
Environmental Legitimacy Through Adopting Green Products and Its Effect on the Brand Equity: Moderating Role of Management Awareness
}

\author{
Tareq N. Hashem ${ }^{1}$ \\ ${ }^{1}$ Marketing Department, Isra University, Amman, Jordan \\ Correspondence: Dr. Tareq N. Hashem, Associate Professor, Marketing Department, Isra University, Amman, Jordan. \\ Tel: 962-795-707-612.
}

Received: November 24, 2020

Accepted: January 13, $2021 \quad$ Online Published: January 27, 2021

doi:10.5430/rwe.v12n2p197

URL: https://doi.org/10.5430/rwe.v12n2p197

\begin{abstract}
The current study sought to examine the influence of adopting green products as a form of environmental legitimacy on "brand equit'y" through the moderating role of management awareness. Quantitative method was adopted through utilizing a questionnaire which was distributed on (96) individuals within green brands producers in Jordan. Results of study indicated that all brand equity variables are influenced by adopting green products as a form of environmental legitimacy. Results also indicated that brand personality was the most influenced variable of all scoring an $\mathrm{R}$ value of (0.74) and explained $54.7 \%$ of total influence. Study recommended organizations to focus on adopting green products in order to enhance brand equity as an approach for developing and supporting sales, and encouraging customers of regular products to switch to green products.
\end{abstract}

Keywords: environmental legitimacy, brand equity, management awareness, green products, brand recognition, brand personality

JEL: F64, Q56, M31

\section{Introduction}

Business organizations have begun to modify their environmental behaviors in the quest to include new social and environmental concerns ( $\mathrm{Li}$ et al, 2018). Many periodicals and jourbals specialized in green marketing, or what is sometimes known as environmental and social marketing, have appeared as an approach to provide semantic researches related to the environmental behavior of business organizations (Yao et al, 2019; Deniz and Onder, 2017). As a result, new terms have emerged, including Green Marketing and Green Consumer Guide in the United States of America which included types of green products, their benefits for the environment, how to market them and their most appropriate point of sales (Alrazi et al, 2010).

Green organizations have emerged as organizations that are interested in providing products of green goods and services in order to preserve the health and safety of consumers, and also, preserve the environment surrounding (Yao et al, 2019; Bettinazzi et al, 2018; Ahmad and Thyagaraj, 2014; Bilgili and Ozkul, 2015; Hong et al, 2012; Alhaddad, 2015; Loureiro et al, 2014). In the nineties of the last century, the concept of green marketing gained the attention of productive and academic organizations. Conferences and seminars were dedicated to highlight the role environmental and social movements and the orientation towards meeting the needs and desires of customers significantly (Mousa and Hassan, 2015). As a result, the concept of 'environmental legitimacy' appeared launching from the fact that legitimacy is "a state where the actions of an entity are appropriate within some socially constructed system of norms, values, beliefs, and definitions" (Li et al, 2018:2). As for environmental legitimacy, is refers to organizations' strategies "to increase their investment in green innovation which involves the generation of new ideas, goods, services, processes, or management systems in effort to reduce environmental pollution and achieve sustainability" ( $\mathrm{Li}$ et al, 2018:2). From that point, organizations began to adopt activities, actions and strategies that would increase the level of their acceptance in the market and develop their reputation among customers. Such actions ranged between producing, adopting and marketing for green products, taking green precautions as the main form of their operations and call for environmental responsibility in the market.

The current study aimed at examining the influence of adopting green products as a form of environmental legitimacy and its influence on brand equity through the moderating influence of brand awareness. 


\section{Model and Hypotheses}

In order to explain the relationship between chosen variables; researcher built the following model:

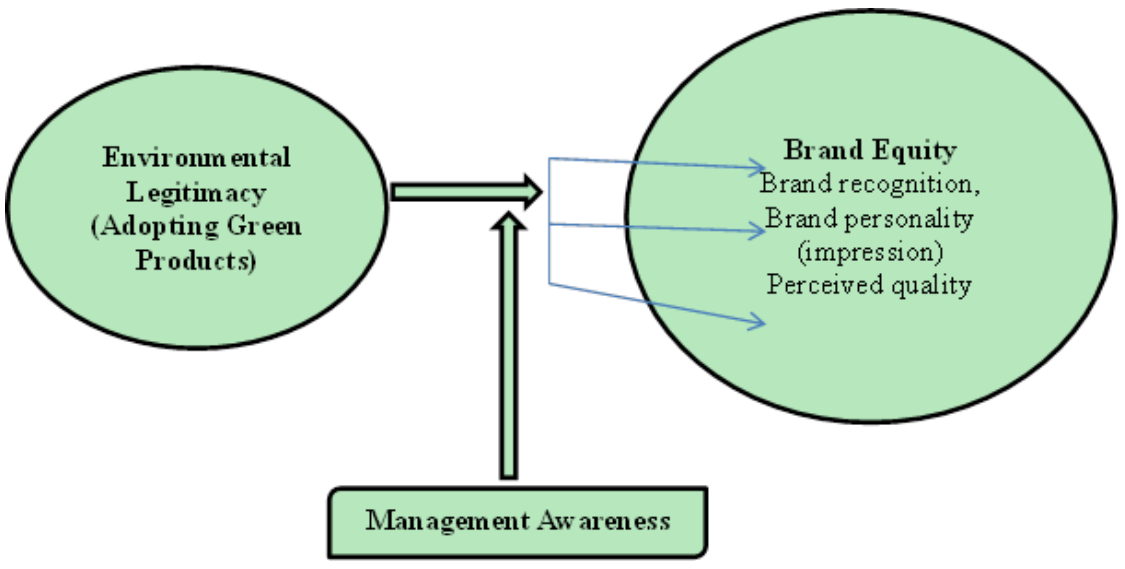

Figure 1. Study Model

Source: Ahmad and Thyagaraj, 2014; Bilgili and Ozkul, 2015; Alhaddad, 2015; Loureiro et al, 2014

\subsection{Study Hypotheses}

H1: Environment legitimacy through adopting green marketing has a positive influence on brand equity

H1a: Environment legitimacy through adopting green marketing has a positive influence on brand recognition,

H1b: Environment legitimacy through adopting green marketing has a positive influence on brand personality (impression)

H1c: Environment legitimacy through adopting green marketing has a positive influence on perceived quality

H2: Management awareness moderates the relationship between environmental legitimacy and brand equity

According to Deniz and Onder (2017:1), green branding and adopting green products as a form of environmental legitimacy "provide an opportunity for the firms to create trust and satisfaction by building a positive image and enhance the brand equity", this has helped in creating green brand equity which is defined as "set of brand assets and liabilities about green commitments and environmental concerns linked to a brand, its name and symbol that add to or subtract from the value provided by a product or service" (Deniz and Onder, 2017:3).

\section{Literature Review and Hypotheses Development}

\subsection{Environmental Performance}

The level of environmental performance is one of the factors that are considered by stakeholders when determining the environmental legitimacy of the firm (To, \& Lee, 2014; Testa et al., 2014). According to (Hawn \& Ioannou, 2016) environmental performance reflects the impact of a firm's operations on the environment. This includes how the firm uses water, energy and materials, how it manages effluents, emissions, and waste discharges. These activities may impact biodiversity, products and services as well as its compliance to the existing environmental regulations and laws (GRI, 2013). The environmental condition and impact indicators identified by To and Lee (2014) and the environmental results measurement aspects identified by Zhang, Wang and Wang (2014), are dimensions of environmental performance which is largely limited to the impact or outcome of the firm's operations on the environment.

For Tadros and Magnan (2019), environmental performance moderates the effects of legitimacy and economic incentives on the propensity of the firm to offer proprietary environmental disclosure. Tadros and Magnan (2019) and others (e.g., Samkin, 2012; Massa et al., 2015; Wisner, Epstein, \& Bagozzi, 2010) consider environmental performance and environmental reporting as constituting environmental accountability noting that improvement in environmental performance may lead to environmental sustainability and that environmental performance does influence the organizational legitimacy by influencing the level of stakeholder satisfaction. In view of these studies, 
organizations seeking to attain environmental legitimacy must strive to improve environmental performance which can be achieved by the firm taking keen interest in how its activities affect the environment.

\subsubsection{Environmental Legitimacy}

Devinney, Mcgahan, and Zollo (2013) saw legitimacy as a generalized assumption or perception that an entity's actions are appropriate, desirable, proper and in line with socially construction system of definitions, beliefs, values, and norms. In an attempt to contextualize legitimacy from the environmental perspective, Durand and Jacqueminet (2015), described environmental legitimacy - as was also agreed on by Zollo et al. (2016) - as referring to the indications that a certain organization's activities and operations are for the benefit of the environment and supports the sustainable development of the surrounding space. Davari and Strutton (2014) further emphasized that for a firm to reach legitimacy, its environmental performance must reflect the stakeholders' expectations, way of thinking, approaches and ideology. Other researchers (e.g., Chang, 2011) see legitimacy as complex concept in that it is culturally and temporary defined but still it emphasizes the social responsibility of organizations towards the society. Emphasizing this view, Meng et al. (2014), pointed that the need for organizations to gain legitimacy arises because an organization is an entity within the society must operate through social contract, and that its existence, growth and continuity is largely dependent on the societal continuous support. Clarkson et al. (2011), highlighted conditions for a society permitting the organization to create a social contract as providing support to a firm and gaining legal standing by sourcing labor and resources from the society. In return the society expects the firm to undertake goals in a socially desirable and acceptable manner. These expectations can be implicit (i.e., hypothetical, informal and based on moral grounding and justifications) or explicit (i.e., formal and expressed in regulations and laws (Glennie, \& Lodhia, 2013; Meng et al., 2014).

These studies suggest that for a firm to grow and survive in a society, it must operate within the existing legal constraints, secure adequate resources, and act in conformity with the existing moral and norms of the society (Pellegrino, \& Lodhia, 2012). According to Pellegrino and Lodhia (2012) operating within the prevailing legal constraints can help a firm to gain legal legitimacy while from the market perspective; security adequate resources can help it obtain operational legitimacy. On this ground, legitimacy occurs when a firm's actions, including its methods of operation, goals, and output are consistent with social expectations. On the contrary, organizational legitimacy can be under a threat and thus cause a legitimacy gap when operations and activities on an organization do not match the social expectations when it comes to environment.

As noted by Pellegrino and Lodhia (2012), factors that may contribute to a legitimacy gap include changing social expectations, altering organizational performance, or when these two happens. In general, environmental legitimacy is conditional in that depends on public assessment of environmental performance of a corporation and its environmental accountability (environmental reporting). This demands that the firm should invest in stakeholder management through environmental proactivity, and investing in environmental accounting and management systems.

\subsubsection{Internal Adaptation Initiatives}

Stakeholders take into account the internal adaptation initiatives when assessing the environmental legitimacy or performance of a firm (Hawn \& Ioannou, 2016). Stakeholders look at the organization's behavior towards the environment by looking at the current and future environmental impact. Stakeholders may see the firm as sensitive to the environment when putting in effort to investing in minimizing the negative impact on the environment irrespective (To, \& Lee, 2014; Wisner, Epstein, \& Bagozzi, 2010).

Stakeholders are likely to perceive the firm as improving environmental performance if it changes its operating products and processes and its efforts are seen as geared towards monitoring the environmental effects of its activities. Initiatives and efforts that adapt products and processes of a firm can influence stakeholders to view the firm as investing in environmental improvement. According to Berrone et al. (2017) efforts such as applying for environmental patterns, adapting environmental patents, and establishing board committees that deals with environmental issues influence stakeholders into gaining confidence that an organization is proactively concerned with improve future performance and reactionary compliance. The organization understands on the outcome of sustainability efforts and initiatives and the initial environmental impact demonstrates its commitment to change process (Glennie, \& Lodhia, 2013).

\subsubsection{Green Product Adoption}

For corporations to gain, repair and sustain environmental legitimacy, they are required to invest in green innovation, including adopting green products. Green innovations entails generating new goods, services, ideas, processes, and 
management systems aimed at achieving sustainability and reducing environmental pollution. Corporations with green products are known to be more inclined towards disclosing their carbon information with a view to gaining motivation, capability and confidence. As noted by Chang (2011), green innovation can offset the environmental investment costs, increase the value of products, improve environmental and economic performance, as well as meet the prevailing environmental regulations (Chang, 2011). Adequate financial resources and positive environmental performance can improve the level and quality of the organization's environmental information disclosure (Clarkson et al. 2011).

Corporations improve their environmental and economic performance by adopting green products or innovations achieved by meeting the needs of environmentally sensitive consumers, lowering costs, and increasing operational efficiency (Chang, 2011). As indicated by Chang (2011), green products or innovation capacity helps a firm to obtain and maintain a competitive advantage. Similarly, Kinoti (2011) argued that green products helps corporations improve their performance as well as reduce cost. For Wisner, Epstein, and Bagozzi (2010), green innovations positively impacts the turnover rates. Through green innovations, a corporation can improve its financial and environmental performance. Green products/innovation also helps corporation to be capable of building routinized framework for disclosing carbon information to satisfy stakeholders (Meng et al.2014; Clarkson et al., 2011). According to Davari and Strutton (2014) green products tend to be less toxic and are created via an environmentally friendlier processes and aspects (e.g., recycling, reuse, minimizing packaging materials, enhancing the durability of a product, reparability, safer products, and consideration in product disposal (Kinoti, 2011).

\subsubsection{International Scale of Initiatives}

Stakeholders also consider the international scale of environmental initiatives when assessing the environmental performance of a firm. This relates to the corporations' environmental activities and how these activities are coordinated at the global level. As highlighted by Sdrolia, and Zarotiadis (2018), increasing international operations influences firms to choose the extent to which the implement and coordinate global practices from their headquarters or become irresponsive to local needs. It is worth noting that such a choice may have consequences to the overall legitimacy of the firm. In general, many multinationals experience immense pressure to be environmentally responsible at the international level (Devinney, McGahan \& Zollo, 2013). As noted by Zollo et al. (2016) stakeholders at the global level have increasingly become sensitive to climate change and other environmental issues that require responses from the firms operating at the global level. According to Zollo et al. (2016) large-scale initially promoted by multinational firms can influence stakeholders' stance towards the firm's environmental sensitivity. Other studies show that stakeholders tend to favor standardized environmental approaches and they expect corporations to coordinate and execute their environmental policies at the global level (Clarkson et al., 2011). Reinforcing this view Tseng, and Hung (2013), argued that a firm can demonstrate their compliance with the stakeholders' demands and standards of environmentally sustainable and responsible behavior by implementing environmental practices globally on a large scale. On this account, Durand and Jacqueminet (2015) suggest that legitimacy is favored by a firm globally harmonizing environmental practices, and striving to minimize risks of legitimacy spillovers, and reducing consequences of irresponsibility transfers.

\subsection{Brand Equity}

Brand equity is widely considered an added value to the firm. It is the sum of assets such as loyalty, perceived quality, awareness, and other propriety assets associated with brand name (Berrone et al., 2013). Biswas, and Roy (2015), consider brand equity as a reflection of the mental image of brand identity and as reflecting the consumer. For Carrillo-Hermosilla, Río, and Könnölä (2010), brand equity is grounded in brand knowledge and awareness. For others (e.g., Biswas, and Roy, 2015), brand equity is an external and internal process to the organization that involves a firm providing a value proposal through a brand. The commonality in these definitions is that brand equity does add value to a service or good being offered by a company.

Amores-Salvadó et al. (2014) considered brand equity as multidimensional concept encompassing perceived quality, brand recognition, and brand personality. Amores-Salvadó et al. (2014) contextualized brand equity as a set of brand liabilities and assets associated with a brand, its symbol, and name that subtracts or adds the value offered by a service or product to an organization or its customers.

\subsubsection{Brand Recognition}

As described by Brasil et al. (2015), brand recognition or awareness is the degree to which a customer can identify correctly a product or service based on its tag, line, logo, advertising campaign or packaging. Brand awareness or recognition can also be identified or triggered through audio cue. Keller (2013) lists brand recognition or brand 
awareness as one of the dimensions of brand equity. Keller (2013) developed a model that demonstrates that name awareness is one on the dimensions of brand equity; others are listed as brand loyalty, brand associations, perceived quality, and other proprietary brands assets. Keller (2013) observed that recognition of a brand largely depends on the consumers' experience with the brand and the relationship between consumers. In this way, Keller (2013) considered brand equity as different in effects on reactions made by consumers in relation to marketing a brand. These effects are known to vary with the knowledge a customer have regarding the brand. According to Brasil et al. (2015), these effects are determined by making a comparison in consumers' reactions towards well-known brand's marketing activities compared to unknown brands.

\subsubsection{Brand Personality (Impression)}

Consumers differ in their recognition of competing brands depending on brand impression or personality. Brand impression is the human qualities granted to a brand in a process referred in anthropomorphizing. According to Maehle et al. (2011), humans often create brand impression as a natural tendency to anthropomorphize non-human objects. This is an attempt for consumers to explain products based on their conceptions and experiences (Sung \& Kim, 2010).

Through anthropomorphizing, non-human products appear human-like. In this way, anthropomorphizing helps consumers gain reassurance and comfort when interacting with anthropomorphized products. Other studies indicate that brand personality serve the emotional symbolic purpose as consumers tend to naturally create relationships with brands and identify them with personality characteristics (e.g., confident, elegant) (Wei, Chiang, Kou, \& Lee, 2017). Reinforcing this view, Ali, and Ahmad (2012), pointed that brand personality is typically human characteristics that consumers associate with a brand. According to Ali, and Ahmad (2012), brand personalities allow consumers to identity with a brand as well as express their personality via a brand by performing a self-expressive or symbolic function. This emotional ties and symbolic meanings help establish meaningful consumer-brand relationships, and helps consumers to create, reinforce and form their self-brand links with the brand (Sung \& Kim, 2010).

\subsubsection{Perceived Quality}

Perceived quality is identified by Hazen, Mollenkopf, and Wang (2017) as one of the four core elements of brand equity. According to Hazen, Mollenkopf, Wang, \& Y., 2017, perceived quality and brand association in general helps differentiate/position, communicate information, reason-to-buy, basis for extensions, and create position feelings/attitude. Hazen, Mollenkopf, and Wang (2017) relate perceived quality to the consumers' opinion or suggestions with regard to the extent to which a product meets their expectations. For Aman et al. (2012), perceived quality is the consumers' view of the product or service quality in terms of their expectations and compared to how the view the quality of other products on offer. Similarly, Liu, Yang, and Xu (2017) view perceived quality as the consumers' evaluation of the overall superiority or excellence of a product of a service. Catulli and Reed (2017) further emphasizes that perceived quality is a perceived judgment by a consumer towards a product/service. On this basis, perceived quality is a measure of belief that affects brand associations and profitability. Catulli and Reed (2017) indicates that the extent to which consumers consider a brand to offer quality is measured based on the following: the number of brand/line extensions, availability in different channels of sale, position or level of differentiation relative to competitor's brands, quality afforded by the brand/product, and price.

Perceived brand quality is believed to influence perceived risks. For this reason, perceived brand quality is believed to strategically affect brand quality (Terenggana, Supit, \& Utami, 2013). Terenggana, Supit, and Utami (2013) noted that customers are likely to infer quality using product attributes such as flavor, availability of production information, appearance and form of the product, and color.

\subsection{Managerial Awareness of Environmental Responsibility}

\subsubsection{Influence of Green Products Adoption on Brand Equity}

It is suggested in the previous literature that organizations seeking to improve their brand equity should seek to gain environmental legitimacy, and should strive to make their products green or embrace green marketing mix. This involves developing green products and executing promotional, distribution and pricing that is aimed at preserving and promoting the environmental welfare and legitimacy (Kinoti, 2011). As observed by Kinoti (2011) green marketing mix is distinguished from traditional marketing mix in that consumers of green marketing mix have a special preference for sustainable consumption habits and sustainable lifestyles that are thought not compromise the future and harm the environment. This reality has influenced firms to seek to understand the buying behaviors and needs of this class of consumers, and they are responding by developing green marketing mix that can better their performance by creating brand equity (Keller, 2013). 
In the literature, studies have suggested that brand equity can be increased by adopting green product mix. For example, Sohall (2017) investigated the relationship between green marketing strategies and consumer-based brand equity (CBBE) dimensions. Results revealed a positive association between elements of green marketing and brand equity and other dimensions of CBBE. Similarly, Moise et al. (2019) investigated the association between brand equity dimensions namely (brand loyalty, perceived quality, brand associations, and brand awareness) and environmentally sustainable practices. Results showed that green practices are positively associated with brand equity and other dimensions of brand equity notably WoM, and customer satisfaction. In a similar study, Chen (2010) used data collected from Taiwan electronic industry using a questionnaire to explore the relationship between green brand equity and (green brand image, green trust, and green satisfaction) achieved by adopting green products. Result revealed that green brand equity is associated with (green trust, green satisfaction and green brand image) all achieved by adopting green products. The researcher concluded that brand equity can be enhanced by adopting green products as this could increase green satisfaction, green trust and green image.

In another study, Namkung and Jang (2013) surveyed 512 American diners with a view to find out if there was a relationship between green practices adopted by a restaurant and customer-based brand equity. The aim was to ascertain whether green practices really mattered. The result showed that implementing green practices notably environmentally focused green practices and food focused green practices enhanced customers' behavioral intentions to purchase the product. These practices were also found to influence perception of customers towards green brand equity. However, the study did not find significant association between green practices and perceived quality. The study finding also showed that diners that were thought to have high environmental-consciousness and health are more positively favored by customers than those seen as not environmental-consciousness.

\section{Methodology}

Current study was built adopting quantitative approach through utilizing a questionnaire. The questionnaire was divided into two sections; the first took into perspective demographics of study sample, while the other section presented statements related to study variables (adopting green products, brand equity dimensions and management awareness). The questionnaire was built on likert 5 scale (5 strongly agree, 4 agree, 3 neutral, 2 disagree, 1 strongly disagree).

Population of study focused on green products in Jordan which reached to (60) brands, marketing and production managers from each brand were chosen and constituted total of (180) individuals. A sample of (123) individuals was chosen to represent the population, after application process researcher found out that (96) questionnaires were properly filled giving an indication of $(93.2 \%)$ which was statistically accepted.

AMOS was used to screen and analyzed gathered data, Cronbach alpha was employed to test the reliability of study questionnaire, as shown in the following table; Alpha value for each variable was acceptable since it was greater than the value 0.60 :

Table 1. Reliability Test Results

\begin{tabular}{ll}
\hline & Alpha value \\
\hline Environmental Legitimacy & .878 \\
\hline Brand recognition & .896 \\
\hline Brand personality (impression) & .782 \\
\hline Perceived quality & .874 \\
\hline Management Awareness & .944
\end{tabular}

Source: spss output for the study

\section{Statistical Analysis}

\subsection{Demographic Results}

Responses of sample individuals according to demographics were calculated, results of analysis indicated that majority of sample responded to questionnaire was males scoring $(66.7 \%)$ of total sample, as for age range it appeared that the majority of respondents were above 40 years old scoring $(44.8 \%)$ of total sample, academic qualifications appeared to be for the benefit of PhD holders scoring (31.3\%) of the sample who had an experience of 
(8-13) years forming $(30.2 \%)$ of total sample.

\subsection{Questionnaire Analysis}

Attitudes of respondents regarding questionnaire statements were calculated in Table 2; it appeared through analysis that respondents had positive attitudes towards statements of questionnaire as they scored higher than mean of scale 3.00 indicating an accepted result.

Table 2. Environmental legitimacy

\begin{tabular}{lcc}
\hline & Mean & Std. Deviation \\
\hline Being environmentally legitimate is a crucial for the organization & 3.0521 & 1.37932 \\
\hline $\begin{array}{l}\text { Management has high awareness of the influence of adopting green product } \\
\text { to the environmental responsibility strategy }\end{array}$ & 3.6458 & 1.23952 \\
\hline $\begin{array}{l}\text { Organization appreciates level of environmental awareness among people } \\
\text { now }\end{array}$ & 3.4792 & 1.23100 \\
\hline $\begin{array}{l}\text { Adopting green product as a sign of environmental legitimacy increases } \\
\text { profit on the long run }\end{array}$ & 3.2396 & 1.44182 \\
\hline $\begin{array}{l}\text { Adopting green product means more legitimacy of the organization among } \\
\text { customers }\end{array}$ & 3.1146 & 1.44273 \\
\hline $\begin{array}{l}\text { Embracing green products means to hold environmental responsibility } \\
\text { Environmental legitimacy }\end{array}$ & 3.3021 & 1.21499 \\
\hline
\end{tabular}

Source: spss output for the study

As it can be seen from Table 2, the most positively answered statement was for environmental legitimacy variable which is the independent variable, the most influential statement appeared to be "Management has high awareness of the influence of adopting green product to the environmental responsibility strategy" scoring (3.64) while the lowest positively answered statements was articulated "Being environmentally legitimate is a crucial for the organization " scoring a mean of (3.05) but still higher than mean of scale which was seen as a positive result.

Table 3. Brand recognition

\begin{tabular}{lcc}
\hline & Mean & Std. Deviation \\
\hline $\begin{array}{l}\text { Customers recognize our products because they are healthy and } \\
\text { eco-friendly }\end{array}$ & 3.5000 & 1.17876 \\
\hline $\begin{array}{l}\text { Our products are available in every store because they are green and } \\
\text { recognizable }\end{array}$ & 3.1458 & 1.38396 \\
\hline Green products are mostly memorable & 3.5729 & 1.29570 \\
\hline Environmentally legitimate organizations appeal customers & 3.5521 & 1.26383 \\
\hline Presenting green products gives customers feelings of its simplicity & 3.2500 & 1.26491 \\
\hline Brand recognition & 3.4042 & 1.07526 \\
\hline
\end{tabular}

Source: spss output for the study

As it can be seen from Table 3, the most positively answered statement was for brand recognition variable which is one of the dependent variables, the most influential statement appeared to be "Green products are mostly memorable" scoring (3.57) while the lowest positively answered statements was articulated "Our products are available in every store because they are green and recognizable" scoring a mean of (3.14) but still higher than mean of scale which was seen as a positive result. 
Table 4. Brand personality (impression)

\begin{tabular}{lcc}
\hline & Mean & Std. Deviation \\
\hline Green products standout as they tend to have a vivid impression & 3.7188 & 1.16712 \\
\hline Green products give a more environmental attitude to the organization & 3.6354 & 1.15275 \\
\hline Green products is considered to be an added value to the brand & 3.4062 & 1.42591 \\
\hline Identifying the brand as green gives it more personality & 3.2604 & 1.63027 \\
\hline Identifying a brand as green makes it safe to use among customers & 3.0938 & 1.52231 \\
\hline Brand personality (impression) & 3.4229 & 1.01851 \\
\hline
\end{tabular}

Source: spss output for the study

As it can be seen from Table 4, the most positively answered statement was articulated brand personality variable which is one of the dependent variables, the most influential statement appeared to be "Green products gives a more environmental attitude to the organization" scoring (3.63) while the lowest positively answered statements was articulated "Identifying a brand as green makes it safe to use among customers" scoring a mean of (3.09) but still higher than mean of scale which was seen as a positive result.

Table 5. Perceived quality

\begin{tabular}{lcc}
\hline & Mean & Std. Deviation \\
\hline Customers feel happy as products don't harm the environment & 3.4583 & 1.12312 \\
\hline Customers feel involved when they buy green products & 3.5313 & 1.21355 \\
\hline $\begin{array}{l}\text { Environmental issues become part of the purchasing process } \\
\text { customer buy them }\end{array}$ & 3.3854 & 1.10853 \\
\hline Customers feel that green products are an added value & 3.6146 & 1.20848 \\
\hline Green products are generally appealing to customers & 3.3021 & 1.31485 \\
\hline Perceived quality & 3.4583 & .97588 \\
\hline
\end{tabular}

Source: spss output for the study

As it can be seen from Table 5, the most positively answered statement was for perceived quality variable which is one of the dependent variables, the most influential statement appeared to be "Customers feel that green products are an added value" scoring (3.61) while the lowest positively answered statements was articulated "Green products are generally appealing to customers" scoring a mean of (3.30) but still higher than mean of scale which was seen as a positive result.

Table 6. Management awareness

\begin{tabular}{lcc}
\hline & Mean & Std. Deviation \\
\hline $\begin{array}{l}\text { Management and stakeholder tend to hold responsibility of environmental } \\
\text { issues }\end{array}$ & 3.2917 & 1.39107 \\
\hline $\begin{array}{l}\text { Management is aware that environmental legitimacy has an influence on } \\
\text { organizations' reputation }\end{array}$ & 3.4167 & 1.35853 \\
\hline $\begin{array}{l}\text { Management spreads awareness among employees on the importance of } \\
\text { environment related responsibilities }\end{array}$ & 3.4062 & 1.26140 \\
\hline The organization has a sufficient green consideration & 3.2813 & 1.38186 \\
\hline $\begin{array}{l}\text { The information or database concerning green specifications is adequately } \\
\text { available in the organization }\end{array}$ & 3.3542 & 1.32966 \\
\hline Senior management is willing to support green specifications & 3.4688 & 1.38376 \\
\hline Management Awareness & 3.3663 & 1.19272 \\
\hline
\end{tabular}

Source: spss output for the study 
As it can be seen from Table 6, the most positively answered statement was for the moderating variable (management awareness), the most influential statement appeared to be "Senior management is willing to support green specifications" scoring (3.46) while the lowest positively answered statements was articulated "The organization has a sufficient green consideration" scoring a mean of (3.28) but still higher than mean of scale which was seen as a positive result.

\subsection{Hypotheses Testing}

Linear regression was used to test following hypothesis:

H1: Environment legitimacy through adopting green marketing has a positive influence on brand equity

Table 7. Testing H1

\begin{tabular}{lllll}
\hline Model Summary & & & & \\
\hline Model & $\mathrm{R}$ & R Square & F & Sig. \\
\hline 1 & .809 & .655 & 178.290 & .000
\end{tabular}

\section{Coefficients}

\begin{tabular}{|c|c|c|c|c|c|c|}
\hline \multirow{2}{*}{\multicolumn{2}{|c|}{ Model }} & \multicolumn{2}{|c|}{ Unstandardized Coefficients } & Standardized Coefficients & \multirow[b]{2}{*}{$\mathrm{t}$} & \multirow[b]{2}{*}{ Sig. } \\
\hline & & $\overline{\mathrm{B}}$ & Std. Error & Beta & & \\
\hline 1 & (Constant) & 1.095 & .183 & & 5.973 & .000 \\
\hline & Environmental Legitimacy & .706 & .053 & .809 & 13.353 & .000 \\
\hline
\end{tabular}

Source: spss output for the study

It was found that $\mathrm{r}=0.809$ reflected high and positive relationship between the independent variable and the dependent variable. Also, it was found that the independent variables explained $65.5 \%$ in the variance of the dependent variable. Also it was found that $\mathrm{F}$ value was significant at 0.05 level, that meant Environment legitimacy through adopting green marketing has a positive influence on brand equity

H1a: Environment legitimacy through adopting green marketing has a positive influence on Brand recognition

Table 8. Testing H1a

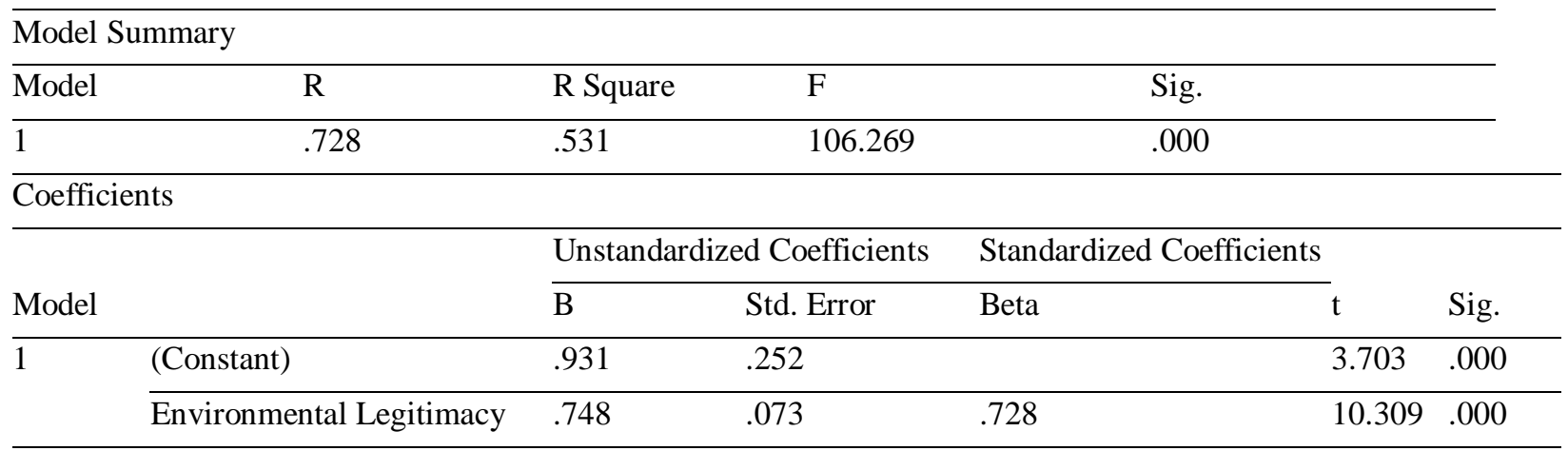

Source: spss output for the study

It was found that $\mathrm{r}=0.728$ reflects high and positive relationship between the independent variable and the dependent variable. Also, it was found that the independent variables explained $53.1 \%$ in the variance of the dependent variable. Also it was found that $\mathrm{F}$ value was significant at 0.05 level, that meant Environment legitimacy through adopting green marketing has a positive influence on Brand recognition,

H1b: Environment legitimacy through adopting green marketing has a positive influence on Brand personality (impression) 
Table 9. H1b

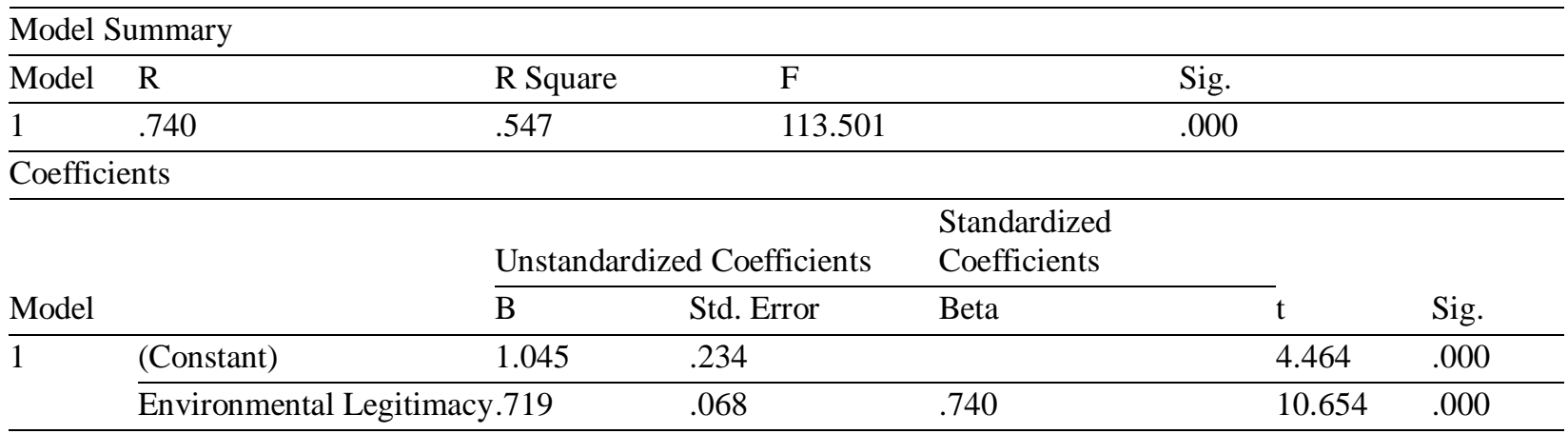

Source: spss output for the study

It was found that $\mathrm{r}=0.74$ reflected high and positive relationship between the independent variable and the dependent variable. Also, it was found that the independent variables explained $54.7 \%$ in the variance of the dependent variable. Also it was found that $\mathrm{F}$ value was significant at 0.05 level, that means Environment legitimacy through adopting green marketing has a positive influence on Brand personality (impression)

H1c: Environment legitimacy through adopting green marketing has a positive influence on Perceived quality

Table 10. Testing H1c

\begin{tabular}{|c|c|c|c|c|c|c|c|}
\hline \multicolumn{7}{|c|}{ Model Summary } & \\
\hline$\overline{\text { Model }}$ & $\mathrm{R}$ & \multicolumn{2}{|c|}{ R Square } & $\mathrm{F}$ & \multicolumn{2}{|c|}{ Sig. } & \\
\hline 1 & .698 & \multicolumn{2}{|c|}{.487} & 89.312 & \multicolumn{2}{|c|}{.000} & \\
\hline \multicolumn{8}{|c|}{ Coefficients } \\
\hline & & & \multicolumn{2}{|c|}{ Unstandardized Coefficients } & \multicolumn{2}{|c|}{ Standardized Coefficients } & \\
\hline \multicolumn{2}{|l|}{ Model } & & $\mathrm{B}$ & Std. Error & Beta & $\mathrm{t}$ & Sig. \\
\hline \multirow[t]{2}{*}{1} & (Constant) & & 1.308 & .239 & & 5.482 & .000 \\
\hline & Environme & hacy & .651 & .069 & .698 & 9.450 & .000 \\
\hline
\end{tabular}

Source: spss output for the study

It was found that $r=0.698$ reflects high and positive relationship between the independent variable and the dependent variable. Also, it was found that the independent variables explained $48.7 \%$ in the variance of the dependent variable. Also it was found that $\mathrm{F}$ value was significant at 0.05 level, that meant Environment legitimacy through adopting green marketing has a positive influence on Perceived quality

H2: Management awareness moderates the relationship between environmental legitimacy and brand equity

Table 11. Testing H2

$$
\text { Model Summary }
$$

\begin{tabular}{|c|c|c|c|c|c|c|c|c|c|}
\hline \multirow[b]{3}{*}{ Model } & \multirow[b]{3}{*}{$\mathrm{R}$} & \multirow{3}{*}{ R Square } & \multirow{3}{*}{$\begin{array}{l}\text { Adjusted } \\
\text { Square }\end{array}$} & \multirow{3}{*}{${ }^{R}$} & \multicolumn{5}{|c|}{ Change Statistics } \\
\hline & & & & & $\mathrm{R}$ & & & & \\
\hline & & & & & Change & F Change & df1 & $\mathrm{df} 2$ & Sig. F Change \\
\hline 1 & .814 & .662 & .659 & 184.460 & .662 & 184.460 & 1 & 94 & .000 \\
\hline 2 & .851 & .724 & .718 & 122.004 & .062 & 20.764 & 1 & 93 & .000 \\
\hline 3 & .858 & .736 & .727 & 85.436 & .012 & 4.118 & 1 & 92 & .045 \\
\hline
\end{tabular}

Source: spss output for the study 
We notice from Table (11), the existence of an effect of environmental legitimacy on brand equity, as the value of $\left(\mathrm{R}^{2}=0.662, \mathrm{p} \leq 0.5\right)$. The Management awareness variable was added in the second step, and it was found that it added $\Delta \mathrm{R}^{2}=6.2 \%$ of the total interpretation factor and it was significant value. The interaction between environmental legitimacy and Management awareness variable was added in the third step, and it was found that it added $\Delta \mathrm{R}^{2}=1.2 \%$ of the total interpretation factor and it is significant value. That means Management awareness moderates the relationship between environmental legitimacy and brand equity.

\section{Results}

The current study aimed at examining the influence of adopting green products as a form of environmental legitimacy on brand equity through the moderating role of management awareness. Quantitative method was through utilizing a questionnaire which was distributed on (96) individuals within green brands in Jordan. Results of study were as follows:

There appeared a positive attitude from respondents regarding questionnaire and variables of study as all their responses presented a positive influence, this indicated a high awareness of respondents regarding brand equity and the role of management awareness in driving attention of organizations towards green products.

Through analysis, it was seen that all brand equity variables were influenced by adopting green products as a form of environmental legitimacy. The most influenced variable appeared to be Brand personality (impression) which scored an $r$ value of (0.74) and formed $54.7 \%$ of total influence.

Brand recognition came in the 2nd rank of influence as adopting green products managed to influence brand recognition with a percentage of $53.1 \%$ scoring an $\mathrm{R}$ value of $(0.728)$.

Perceived quality came in the last rank with an influence of $48.7 \%$ the relationship and scoring an $\mathrm{R}$ value of 0.698

In an overall estimation, result of study indicated that management awareness moderates the relationship between adopting green products and brand equity and emphasized that adopting green products has the ability to positively influence brand equity if the management had the needed awareness regarding green adoption.

The study proved that there is a significant impact of adopting environmental concepts and preserving the environment on the brand through the positive impact that the management awareness can have. With the great openness that the world is witnessing, and the increasing level of consumer awareness of various environmental problems, and consumers' tendencies towards adopting environmental problems and trying to solve them; Brands have become inclined to what the consumer tends to, which is to preserve the environment, in order to ensure the continued interest of consumers in the brand, which leads to its durability.

Through the results, it has been demonstrated that there is an impact of adopting green products in creating the so-called "green brand equity", which indicates the concern for environmental matters and the adoption of environmental responsibility by organizations contributed significantly to the formation of a high-value brand. This came as a result of consumers' tendency to use this brand because of its interest in environmental affairs, and thus the adoption of green products had an impact on the dimensions of brand equity.

Focusing more on analysis, it can be seen that brand personality was the most influenced dimension of brand equity by adopting green products. This can be attributed to the managerial awareness which plays a role in demonstrating the impact of becoming green in the market, and how it can give the brand a personality that is attractive to customers. Results agreed with Maehle et al. (2011); Wei et al (2017) and Ali, and Ahmad (2012) who also agreed on the fact that a adopting green thinking among organizations have an influence on strengthening how a brand appears among customers and attracts them more to become more interested in purchasing the brand.

\section{Conclusion and Recommendations}

In the midst of the increasing pressure by customers regarding environmental matters and concerns for the environment; green marketing has become one of the options available to marketers in order to achieve the desired balance between profit and environmental performance in addition to customer satisfaction. By reference to the results of the study, it was found that the awareness of management and stakeholders of the extent of interest of the public in environmental matters today is one of the motives that will increase the organization's interest in adopting green products as a mean of preserving the quality of the brand and its market value.

The adoption of green products as one of the environmental responsibility strategies helped in forming consumer values and converting these values into buying green products, as the awareness of management and stakeholders for this idea has proven its impact in assimilating the emotional content of individuals and thus stimulating the consumer decision-making process. 
Study recommended that marketers have to better understand why people buy and prefer green products and organizations through focusing on adopting green products in order to enhance brand equity which may lead to enhancing sales and encouraging customers of non-environmentally friendly products to switch to green products.

\section{References}

Ahmad, A., \& Thyagaraj, K. S. (2014). Brand personality and brand equity research: Past developments and future directions. IUP Journal of Brand Management, 11(3), 19.

Alakent, E., \& Ozer, M. (2014). Can companies buy legitimacy? Using corporate political strategies to offset negative corporate social responsibility records. Journal of Strategy and Management, 7(4), 318-336.

Alhaddad, A. (2015). Perceived quality, brand image and brand trust as determinants of brand loyalty. Journal of Research in Business and Management, 3(4), 1-8.

Ali, L., \& Ahmad, I. (2012). Environment friendly products: Factors that influence the green purchase intentions of Pakistani consumers. Pakistani Journal of Engineering Technology and Science, 2(1), 84-117.

Alrazi, B., De Villiers, C., \& Van Staden, C. (2010). A Framework for the integration of Environmental Legitimacy, Accountability and Proactivity (ELAP). Environment, 6(8).

Aman, A. H. L., Harun, A., \& Hussein, Z. (2012). The influence of environmental knowledge and concern on green purchase intention the role of attitude as a mediating variable. British Journal of Arts and Social Sciences, 7(2), 145-167.

Amores-Salvadó, J., Martín-de Castro, G., \& Navas-López, J. E. (2014). Green corporate image: Moderating the connection between environmental product innovation and firm performance. Journal of Cleaner Production, 83, 356-365.

Apergis, N., Eleftheriou, S., \& Payne, J. E. (2013). The relationship between international financial reporting standards, carbon emissions, and R\&D expenditures: Evidence from European manufacturing firms. Ecological Economics, 88, 57-66.

Beelitz, A., \& Merkl-Davies, D. M. (2012). Using discourse to restore organisational legitimacy: 'CEO-speak' after an incident in a German nuclear power plant. Journal of Business Ethics, 108(1), 101-120.

Berrone, P., Fosfuri, A., Gelabert, L., \& Gomez-Mejia, L. R. (2013). Necessity as the mother of 'green' inventions: Institutional pressures and environmental innovations. Strategic Management Journal, 34(8), 891-909.

Bettinazzi, E. L. M., Jacqueminet, A., Neumann, K., \& Snoeren, P. M. (2018, July). Exploring Conditions for Environmental Legitimacy: Evidence from the Energy Industry. In Academy of Management Proceedings (Vol. 2018, No. 1, p. 11757). Briarcliff Manor, NY 10510: Academy of Management.

Bilgili, B., \& Ozkul, E. (2015). Brand awareness, brand personality, brand loyalty and consumer satisfaction relations in brand positioning strategies (A Torku brand sample). Journal of Global Strategic Management, $9(2)$.

Biswas, A., \& Roy, M. (2015). Green products: An exploratory study on the consumer behaviour in emerging economies of the east. Journal of Cleaner Production, 87, 463-468.

Carrillo-Hermosilla, J., Río, P. D., \& Könnölä, T. (2010). Diversity of eco-innovations: Reflections from selected case studies. Journal of Cleaner Production, 18(10-11), 1073-1083.

Caruana, R., \& Chatzidakis, A. (2014). Consumer social responsibility (CnSR): Toward a multi-level, multi-agent conceptualization of the "other CSR". Journal of Business Ethics, 121(4), 577-592.

Catulli, M., \& Reed, N. (2017). A personal construct psychology based investigation into a product service system for renting pushchairs to consumers. Business Strategy and the Environment, 26(5), 656-671.

Chang, C. H. (2011). The influence of corporate environmental ethicson competitive advantage: The mediation role of green innovation. Journal of Business Ethics, 104(3), 361-370.

Chen, Y. (2010). Brand Image, Green Satisfaction, and Green Trust. Journal of Business Ethics, 93(2), 307-319.

Cho, C. H., Patten, D. M., \& Roberts, R. W. (2014). Environmental disclosures and impression management. In R. P. Hart (Ed.), Communication and language analysis in the corporate world (p. 217). IGI-Global: Hershey, PA.

Clarkson, P. M., Li, Y., Richardson, G. D., \& Vasvari, F. P. (2011). Does it really pay to be green? Determinants and consequences of proactive environmental strategies. Journal of Accounting and Public Policy, 30(2), 122-144.

Clarkson, P. M., Overell, M. B., \& Chapple, L. (2011). Environmental reporting and its relation to corporate environmental performance. Abacus, 47(1), 27-60. 
Cormier, D., \& Magnan, M. (2015). The economic relevance of environmental disclosure and its impact on corporate legitimacy: An empirical investigation. Business Strategy and the Environment, 24(6), 431-450.

Davari, A., \& Strutton, D. (2014). Marketing mix strategies for closing the gap between green consumers' pro-environmental beliefs and behaviors. Journal of Strategic Marketing, 22(7), 563-586.

De Villiers, C., \& Van Staden, C. J. (2010). A framework for the integration of environmental legitimacy, accountability and proactivity. In The 6th Asia Pacific interdisciplinary research in accounting (APIRA) conference. Sydney, New South Wales, Australia.

Deniz, A., \& Onder, L. (2017). Determinants of brand equity in green products: The relationships among green brand image, green trust and green satisfaction. International Journal of Arts Humanities and Social Sciences, 2(111), $2-6$.

Devinney, T. M., Mcgahan, A. M., \& Zollo, M. (2013). A Research Agenda for Global Stakeholder Strategy. Global Strategy Journal, 3(4), 325-337.

Durand, R., \& Jacqueminet, A. (2015). Peer conformity, attention, and heterogeneous implementation of practices in MNEs. Journal of International Business Studies, 46(8), 917-937.

Glennie, M., \& Lodhia, S. (2013). The influence of internal organisational factors on corporate-community partnership agendas: An Australian case study. Meditari Account, 21(1), 52-67.

GRI. (2013). G4 Sustainability Reporting Guidelines. Global Reporting Initiative, Amsterdam.

Hahn, R., \& Lülfs, R. (2014). Legitimizing negative aspects in GRI-oriented sustainability reporting: A qualitative analysis of corporate disclosure strategies. Journal of Business Ethics, 123(3), 401-420.

Hahn, R., Reimsbach, D., \& Schiemann, F. (2015). Organizations, climate change, and transparency reviewing the literature on carbon disclosure. Organization \& Environment, 28(1), 80-102.

Hazen, B. T., Mollenkopf, D. A., \& Wang, Y. (2017). Remanufacturing for the circular economy: An examination of consumer switching behavior. Business Strategy and the Environment, 26(4), 451-464.

Hofer, C., Cantor, D. E., \& Dai, J. (2012). The competitive determinants of a firm's environmental management activities: Evidence from US manufacturing industries. Journal of Operations Management, 30(1), 69-84.

Hong, S., Lee, J., \& Kim, B. H. S. (2012). An analysis of the components and measurement of brand equity in residential areas: A case study of Bundang and Ilsan in Korea. Journal of Asian Architecture and Building Engineering, 11(1), 47-54.

Hrasky, S. (2011). Carbon footprints and legitimation strategies: Symbolism or action?. Accounting, Auditing \& Accountability Journal, 25(1), 174-198.

Klettner, A., Clarke, T., \& Boersma, M. (2014). The governance of corporate sustainability: Empirical insights into the development, leadership and implementation of responsible business strategy. Journal of Business Ethics, $122(1), 145-165$.

Kuo, L., \& Yi-Ju Chen, V. (2013). Is environmental disclosure an effective strategy on establishment of environmental legitimacy for organization?. Management Decision, 51(7), 1462-1487.

Lee, S. Y., Park, Y. S., \& Klassen, R. D. (2013). Market responses to firms' voluntary climate change information disclosure and carbon communication. Corporate Social Responsibility and Environmental Management, 22(1), $1-12$.

Li, D. Y., \& Liu, J. (2014). Dynamic capabilities, environmental dynamism, and competitive advantage: Evidence from China. Journal of Business Research, 67(1), 2793-2799.

Li, D., Huang, M., Ren, S., Chen, X., \& Ning, L. (2018). Environmental legitimacy, green innovation, and corporate carbon disclosure: Evidence from CDP China 100. Journal of Business Ethics, 150(4), 1089-1104.

Li, F., \& Ding, D. Z. (2013). The effect of institutional isomorphic pressure on the internationalization of firms in an emerging economy: Evidence from China. Asia Pacific Business Review, 19(4), 506-525.

Liu, Y., Yang, D., \& Xu, H. (2017). Factors influencing consumer willingness to pay for low-carbon products: A simulation study in China. Business Strategy and the Environment, 26(7), 972-984.

Loureiro, S. M. C., Lopes, R., \& Kaufmann, H. R. (2014). How brand personality, brand identification and service quality influence service brand equity. Cogent Business \& Management, 1(1), 981329.

Massa, L., Farneti, F., \& Scappini, B. (2015). Developing a sustainability report in a small to medium enterprise: process and consequences. Meditari Account, 23(1). 
Meng, X. H., Zeng, S. X., Shi, J. J., Qi, G. Y., \& Zhang, Z. B. (2014). The relationship between corporate environmental performance and environmental disclosure: An empirical study in China. Journal of Environmental Management, 145, 357-367.

Moise, M. S., Gil-Saura, I., Seric, M., \& Moina, M. E. (2019). Influence of environmental practices on brand equity, satisfaction and word of mouth. Journal of Brand Management, 26, 646-657.

Mousa, G., \& Hassan, N. T. (2015). Legitimacy theory and environmental practices: Short notes. International Journal of Business and Statistical Analysis, 2(1).

Namkung, Y., \& Jang, S. (2013). Effects of restaurant green practices on brand equity formation: Do green practices really matter?. International Journal of Hospitality Management, 33, 85-95.

Pellegrino, C., \& Lodhia, S. (2012). Climate change accounting and the Australian mining industry: Exploring the links between corporate disclosure and the generation of legitimacy. Journal of Cleaner Production, 36, 68-82.

Samkin, G. (2012). Changes in sustainability reporting by an African defense contractor: a longitudinal analysis. Meditari Account, 20(2), 134-166.

Sdrolia, E., \& Zarotiadis, G. (2018). A comprehensive review for green product term: from definition to evaluation. Journal of Economic Surveys. https://doi.org/10.1111/joes.12268

Sohall, M. S. (2017). Green Marketing Strategies: How do they Influence Consumer-based brand Equity?. Journal Global Business Advancement, 10(3), 229-245.

Tadros, H., \& Magnan, M. (2019). How does environmental performance map into environmental disclosure? A look at underlying economic incentives and legitimacy aims. Sustainability Accounting, Management and Policy Journal, 10(1), 62-96. https://doi.org/10.1108/SAMPJ-05-2018-0125

Terenggana, C. A., Supit, H., \& Utami, C. W. (2013). Effect of value, consumer trust and attitudes towards intention buy environmentally friendly air conditioners product in south Sumatera. Social Sciences and Humanities, 4(3), 323-335.

Testa, F., Rizzi, F., Daddi, T., Gusmerotti, N. M., Frey, M., \& Iraldo, F. (2014). EMAS and ISO 14001: the differences in effectively improving environmental performance. Journal Clean. Prod., 68, 165-173.

To, W. M., \& Lee, P. K. (2014). Diffusion of ISO 14001 environmental management system: Global, regional, and country-level analyses. J. Clean. Prod., 66, 489-498.

Tseng, S, \& Hung, S. (2013). A framework identifying the gaps between customers' expectations and their perceptions in green products. Journal of Cleaner Production, 59, 174-184.

Wang, W-K., Lu, W-M., \& Wang, S. W. (2014). The impact of environmental expenditures on performance in the U.S. chemical industry. J. Clean. Prod., 64, 447-456.

Wei, C. F., Chiang, C. T., Kou, T. C., \& Lee, B. C. Y. (2017). Toward sustainable livelihoods: Investigating the drivers of purchase behavior for green products. Business Strategy and the Environment, 26(5), 626-639.

Wisner, P. S., Epstein, M. J., \& Bagozzi, R. P., (2010). Environmental proactivity and performance. Adv.Environ. Account.Manag, 4, 105-127.

Yao, Q., Zeng, S., Sheng, S., \& Gong, S. (2019). Green innovation and brand equity: moderating effects of industrial institutions. Asia Pacific Journal of Management, 6(2). Retrieved from https://link.springer.com/article/10.1007/s10490-019-09664-2

Zhang, W., Wang, W., \& Wang, S. (2014). Environmental performance evaluation of implementing EMS (ISO 14001) in the coating industry: Case study of a Shanghai coating firm. J. Clean. Prod., 64, 205-217.

Zollo, M., Bettinazzi, E. L. M., Neumann, K., \& Snoeren, P. (2016). Toward a comprehensive model of organizational evolution: dynamic capabilities for innovation and adaptation of the enterprise model. Global Strategy Journal, 6(3), 225-244.

\section{Copyrights}

Copyright for this article is retained by the author(s), with first publication rights granted to the journal.

This is an open-access article distributed under the terms and conditions of the Creative Commons Attribution license (http://creativecommons.org/licenses/by/4.0/). 